\title{
PENGARUH DIAGNOSA KEPERAWATAN TERHADAP TINGKAT MUTU ASUHAN KEPERAWATAN
}

\author{
Ria Oktaviany \\ Email : riariaok29@gmail.com
}

\begin{abstract}
Abstrak
Mutu asuhan keperawatan adalah penilaian penting terhadap kinerja perawat profesional. Baiknya kualitas pelayanan kesehatan dapat didasarkan dari penilaian asuhan keperawatannya karena perawat adalah profesi yang paling lama serta paling dekat dengan pasien. Mutu asuhan keperawatan dapat berjalan dengan baik tentu karena ada proses yang baik pula. Penentuan diagnosa keperawatan merupakan bagian vital untuk mencapai mutu asuhan keperawatan yang tinggi. Seorang perawat profesional yang berkompeten haruslah mampu menentukan diagnosa keperawatan yang tepat. Jika diagnosa keperawatannya tepat maka asuhan keperawatan yang akan dilakukan oleh perawat juga akan berjalan efektif.
\end{abstract}

\section{Latar Belakang}

Diagnosa keperawatan merupakan sebuah tonggak atau dasar bagi perawat untuk melakukan suatu asuhan keperawatan. Pasien datang ke fasilitas kesehatan tentu memiliki keluhan masing-masing. Dari keluhan inilah perawat dituntut untuk mampu merumuskan diagnosa keperawatan yang baik dan benar. Analisis data terhadap keluhan dan juga keadaan biopsikososio-spiritual pasien kemudian disimpulkan oleh perawat tentang masalah kesehatan yang dialami oleh pasien secara singkat, jelas, pasti, dan akurat.

Dalam praktiknya, PPNI telah menyusun kompetensi yang harus dimiliki oleh seorang perawat. Kompetensi perawat adalah refleksi kompetensi yang harus dimiliki oleh perawat untuk memberikan asuhan keperawatan professional (PPNI, 2013). Penjabaran area kompetensi perawat Indonesia salah satunya pemberi asuhan dan manajemen asuhan keperawatan yang meliputi menerapkan prinsip dasar dalam pemberian asuhan keperawatan dan pengelolaannya, melaksanakan upaya promosi kesehatan dalam pelayanan maupun asuhan keperawatan, melakukan pengkajian keperawatan, melakukan analisis data dan merumuskan diagnosa 
keperawatan, menyusun rencana keperawatan, melaksanakan tindakan keperawatan sesuai rencana, mengevaluasi asuhan tindakan keperawatan, menggunakan komunikasi terapeutik dan hubungan interpersonal dalam pemberi pelayanan dan asuhan keperawatan, menciptakan dan mempertahankan lingkungan yang aman, membina hubungan interprofesional dalam pelayanan maupun asuhan keperawatan, menjalankan fungsi delegasi dan supervise baik dalam pelayanan maupun asuhan keperawatan (PPNI, 2013). Apabila perawat mampu memenuhi kompetensi tersebut maka kepuasan pasien akan meningkat dan juga asuhan keperawatannya dapat berlangsung efisien serta efektif Semakin baik penilaian pasien, maka semakin baik pula mutu pelayanan kesehatan rumah sakit tersebut (Donabedian, 1980). Meningkatnya mutu pelayanan kesehatan rumah sakit ini tak lepas dari peran mutu pelayanan asuhan keperawatan dalam suatu rumah sakit tersebut.

\section{Metode}

Metode yang dipakai unuk mengetahui pengaruh diagnosa keperawatan terhadap mutu pelayanan asuhan keperawatan adalah dengan metode kepustakaan. Metode kepustakaan disini dilakukan dengan cara mengumpulkan sumber-sumber kepustakaan yang relevan dan memiliki keterkaitan dengan judul yang diambil oleh penulis. Sumber yang dipakai oleh penulis berupa jurnal, skripsi, tesis, ebook, dan beberapa karya ilmiah lain yang telah diuji kebenarannya. Sumber-sumber tersebut kemudian dikaji, dieskplorasi, dan dianalisa sehingga penulis dapat menyimpulkan pengaruh diagnosa keperawatan terhadap mutu pelayanan asuhan keperawatan.

\section{Hasil}

Berdasarkan hasil literasi disimpulkan bahwa diagnosa keperawatan sangat berpengaruh dengan tingkat mutu asuhan keperawatan. Diagnosa keperawatan merupakan sebuah kunci untuk mencapai mutu asuhan keperawatan yang baik. Asuhan keperawatan dapat dikatakan berkualitas apabila memenuhi harapan pasien dan juga sesuai dengan kebutuhan pasien. Mutu asuhan keperawatan dapat diukur dengan 5 aspek yaitu daya tanggap (responsiveness), jaminan (assurance), bukti fisik (tangible), perhatian (emphaty), dan keandalan (reliability). Kecakapan serta kesadaran pentingnya diagnosa keperawatan yang tepat dapat memberikan respon positif terhadap peningkatan mutu asuhan keperawatan. Sebuah penelitian mengungkapkan bahwa dalam menentukan diagnosa keperawatan, perawat cenderung malas dan kurang inisiatif untuk menganalisa data dan merumuskan diagnosa keperawatan yang tepat. Setelah melakukan 
pengkajian, perawat hanya tinggal memilih saja diagnosa keperawatan yang telah disediakan di samping format pengkajian tanpa meneliti adanya data yang bervariasi. Sikap inilah yang akan menurunkan kredibilitas kinerja perawat. Asuhan keperawatan yang tadinya jelas dan efektif menjadi buram dan juga berbelit-belit karena diagnosa keperawatan yang tidak tepat. Hal inilah yang mendasari mutu asuhan keperawatan dewasa ini masih dalam kategori cukup. Sebagian besar pasien masih merasa mutu asuhan keperawatan tidak terlaksana secara efektif dan efisien. Alasan yang mendasari penilaian ini bermacam-macam, mulai dari akses terhadap pelayanan keperawatan, kelangsungan pelayanan, hubungan antara perawat dengan pasien dan kenyamanan pasien. Tak hanya itu, kelima aspek indikator mutu asuhan keperawatan dari reponsiveness, assurance, tangible, emphaty, dan reliability juga masih dalam kategori cukup. Keadaan ini sudah cukup menjadi bukti bahwa dengan adanya diagnosa yang baik maka tingkat mutu asuhan keperawatan juga akan baik.

Sistem penegakan diagnosis yang ideal harus memberikan informasi klien yang komprehensif, menunjukkan hasil dan standar klien, memfasilitasi reimbursement dari pemerintah dan dari perusahaan asuransi pembayar, serta berfungsi sebagai dokumen legal (Twardon dan Gartner, 1993: Potter \& Perry; 2009). Penting untuk diketahui bahwa sistem proses keperawatan harus dilakukan secara benar mulai dari tahap pengkajian, penentuan diagnosa, merencanakan tindakan yang akan dilakukan, implementasi dan evaluasi asuhan keperawatan. Setiap tahap memiliki hubungan yang tidak bisa dipisahkan. Apabila salah satu dari langkah tersebut tidak dianalisis dengan tepat maka sistem asuhan keperawatan yang diberikan juga tidak efektif. Pengkajian menjadi tahap yang mendasar, apabila dalam tahap ini perawat tidak mampu menemukan data yang akurat maka perawat akan kesulitan menentukan masalah kesehatan yang sedang dihadapi, perawat akan kesulitan menentukan diagnosa keperawatan yang tepat sehingga ia menjadi bingung tindakan keperawatan apa yang harus diambil. Tetapi sebaliknya, apabila pengkajian data dilakukan dengan akurat dibarengi dengan tingkat pendidikan, kecerdasan, dan intelektual perawat dalam menentukan diagnosa keperawatan maka perawat menjadi yakin tindakan keperawatan apa yang harus dilakukannya. Dengan begitu, asuhan keperawatan tidak menjadi berbelit-belit dan pasien mendapatkan asuhan keperawatan yang tepat sehingga dapat menguranngi lamanya perawatan di rumah sakit atau fasilitas kesehatan lainnya. 


\section{Pembahasan}

Proses keperawatan adalah suatu metode sistematis dalam memberikan asuhan keperawatan yang dilakukan oleh perawat dan bekerjasama dengan pasien (induvidu, keluarga, masyarakat) yang bertujuan untuk mengidentifikasi masalah keperawatan pada diri pasien. Proses keperawatan yaitu dimukai dari melakukan pengkajian, menentukan diagnosa, merencanakan tindakan yang akan dilakukan, melaksanakan tindakan serta mengevaluasi hasil asuhan keperawatan yang telah diberikan dengan berfokus pada pasien, berorientasi pada tujuan yang telah ditetapkan bersama. Orientasi dari pelayanan keperawatan adalah terpacainya tujuan asuhan keperawatan. Proses keperawatan dibentuk semata-mata untuk memenuhi asuhan keperawatan yang diharapkan pasien dan untuk mensejahterakan kesehatan pasien. Beberapa ahli telah menyampaikan pendapatnya tentang proses keperawatan, diantaranya :

1. Florence Nightingale, menyatakan bahwa tindakan dalam asuhan keperawatan harus selalu terpisah dari tindakan medis. Tugas pokok Anda sebagai perawat adalah memenuhi kebutuhan dasar manusianya klien dan menata lingkungan keperawatan menjadi lingkungan yang adekuat untuk pemulihan kondisi klien.

2. Yura and Walsh, menyebutkan proses keperawatan terdiri atas 4 tahap. Perkembangan selanjutnya pada tahun 1982 melalui National Council of State Boards of Nursing menyatakan bahwa proses keperawatan terdiri atas 5 tahap yaitu pengkajian keperawatan, diagnosa keperawatan, perencanaan keperawatan, implementasi dan evaluasi keperawatan.

Tujuan dari proses keperawatan adalah untuk peningkatan mutu asuhan keperawatan. Beberapa tujuan khusus proses keperawatan yaitu :

a. Teridentifikasinya masalah-masalah terkait kebutuhan dasar manusianya klien.

b. Dapat menentukan diagnosa keperawatan.

c. Tersusunnya perencanaan keperawatan yang tepat untuk mengatasi diagnosa keperawatan.

d. Terlaksananya tindakan-tindakan keperawatan secara tepat dan terencana.

e. DiketahuinyaDiketahuinya perkembangan klien. 
f. Dapat ditentukannya tingkat keberhasilan asuhan keperawatan.

Proses keperawatan yang baik akan menghasilkan mutu asuhan keperawatan yang baik pula. Tahapan yang membutuhkan proses berpikir paling kritis adalah tahapan diagnosa keperawatan. Tahapan ini juga merupakan tahapan yang harus dijalani perawat sebelum merencanakan tindakan keperawatan. Diagnosa keperawatan adalah suatu pertanyaan yang menggambarkan respons manusia (keadaan sehat atau perubahan pola interaksi actual/potensial ) dari individu atau kelompok. Diagnosa keperawatan merupakan penilaian klinis tentang respons individu, keluarga, atau komunitas terhadap masalah kesehatan atau proses kehidupan aktual dan juga keadaan biopsikososio-spiritualnya. Diagnosa keperawatan berperan sebagai dasar pemilihan intervensi keperawatan untuk mencapai hasil tempat perawat bertanggung jawab.

Langkah-langkah dalam menentukan diagnosa keperawatan adalah :

I. Klasifikasi data adalah pengelompokakan data-data klien atau keadaan tertentu tempat klien mengalami permasalahan kesehatan atau keperawatan

II. Interpretasi Data adalah membuat interpretasi atas data yang sudah dikelompokkan dalam bentuk masalah keperawatan atau masalah kolaboratif.

III. Menentukan Hubungan Sebab Akibat, yaitu menentukan faktor-faktor yang berhubungan atau faktor risiko yang menjadi kemungkinan penyebab dari masalah yang terjadi.

IV. Merumuskan Diagnosis Keperawatan, yaitu perumusan mengenai masalah kesehatan yang dialami pasien.

Peningkatan mutu pelayanan keperawatan merupakan derajat yang memberikan pelayanan secara efisien dan efektif sesuai dengan standar profesi, standar pelayanan yang dilaksanakan secara menyeluruh sesuai dengan kebutuhan pasien yang diberikan oleh perawat. Pelayanan berkualitas yaitu pelayanan yang memberikan suatu jasa pelayanan keperawatan yang benarbenar sesuai dengan kebutuhan pasien dan menunjuk pada tingkat kesempurnaan pelayanan. Mutu pelayanan keperawatan diukur dengan lima aspek yaitu :

$>$ Jaminan (assurance) : artinya pelayanan yang diberikan staf rumah sakit yang dapat menimbulkan kepercayaan dari pasien terhadap rumah sakit. 
Daya tanggap (responsiveness) : suatu bentuk pelayanan yang diberikan oleh pihak rumah sakit yang meliputi kemampuan perawat menanggapi dan melakukan sesuatu yang diinginkan dan dibutuhkan oleh pasien.

$>$ Bukti fisik (tangible) : adalah tampilan fisik pelayanan keperawatan yang diberikan pihak rumah sakit meliputi penampilan fisik seperti bangunan fisik, kelengkapan fasilitas, kebersihan ruangan dan penampilan fisik pegawai rumah sakit yang dapat di lihat dan dirasakan langsung oleh pasien.

$>$ Perhatian (emphaty) : merupakan ketersediaan rumah sakit untuk peduli, memberikan perhatian pribadi dan kenyamanan kepada pasien sehingga pasien bisa merasakan kenyamanan selama menerima perawatan di rumah sakit.

$>$ Keandalan (reliability) : merupakan kemapuan pihak rumah sakit untuk mewujudkan kemampuan melaksanakan pelayanan keperawatan dengan terpercaya dan akurat.

Keseluruhan aspek tersebut memiliki kesamaan untuk mengukur kemampuan dan kredibilitas seorang perawat profesional. Dasar asuhan keperawatan yang baik adalah penentuan diagnosa keperawatan yang baik. Mutu asuhan keperawatan dapat tergambar dari penegakan diagnosis proses keperawatan (Gillies, 1994). Untuk menentukan diagnosa keperawatan yang tepat dibutuhkan beberapa pengetahuan dan kekerampilan yang harus dimiliki oleh perawat, seperti kemampuan memahami beberapa masalah, faktor yang menyebabkan masalah, batasan dan karakteristiknya, batasan atau ukuran normal dari masalah tersebut, sehingga dapat diambil keputusan yang tepat untuk memecahkan masalah yang diangkat secara rasional dan objektif. Kenyataan di lapangan membuktikan bahwa sebagian besar perawat profesional masih belum memiliki kemampuan yang mumpuni dalam penentuan diagnosa.

Banyak faktor yang mempengaruhinya mulai dari keterbatasan pengetahuan, kurangnya kesadaran, tingginya beban kerja, tidak adanya keseragaman diagnosa antara perawat pada shift sebelumnya, dah diagnosa keperawatan tidak dihubungkan dengan kesenjangan dan pemenuhan kebutuhan pasien. Inilah yang menyebabkan mutu asuhan keperawatan tidak sesuai dengan yang diharapkan pasien. Salah satu indikator keberhasilan dari mutu pelayanan asuhan keperawatan itu adalah kepuasan pasien. Perawat yang bertugas mengasuh pasien selama 24 jam, profesi paling depan dan terdekat dengan penderitaan, dan kesakitan pasien memegang peranan penting 
terhadap kualitas kesejahteraan kesehatan pasien. Karena hal itu, mutu pelayanan keperawatan dikatakan sebagai indikator kualitas pelayanan kesehatan dan menjadi salah satu faktor penentu citra institusi pelayanan kesehatan di mata masyarakat.

Untuk meningkatkan kemampuan diagnosa keperawatan ada beberapa jalur yang dapat ditempuh. Salah satu cara yang paling efektif adalah dengan melibatkan peran manajer keperawatan. Manajer keperawatan berperan penting dalam peningkatan kualitas pelayanan keperawatan. Dengan melakukan berbagai kegiatan pelatihan untuk menentukan diagnosa keperawatan diharapkan mampu meningkatkan kualitas pelayanan. Ketegasan dari pihak manajer terhadap perawat yang malas dalam menentukan diagnosa keperawatan juga perlu diperhatikan. Apabila arahan ini dapat terlaksana dengan baik maka besar kemungkinan mutu pelayanan asuhan keperawatan di suatu fasilitas kesehatan dapat meningkat dan sesuai dengan harapan pasien.

\section{Penutup}

Diagnosa keperawatan adalah suatu pertanyaan yang menggambarkan respons manusia (keadaan sehat atau perubahan pola interaksi actual/potensial ) dari individu atau kelompok. Diagnosa keperawatan merupakan penilaian klinis tentang respons individu, keluarga, atau komunitas terhadap masalah kesehatan atau proses kehidupan actual dan juga keadaan biopsikososio-spiritualnya.

Asuhan keperawatan adalah tindakan yang dilakukan perawat untuk kelangsungan hidup pasien dan aspek-aspek pemeliharaan, rehabilitatif dan prefentif perawatan kesehatannya.

Asuhan keperawatan dapat dilakukan apabila perawat memiliki diagnosa keperawatan. Dengan adanya diagnosa keperawatan, perawat akan mampu berpikir tentang tindakan keperawatan apa yang harus dilakukan untuk kesejahteraan kesehatan pasien. Dengan diagnosa keperawatan yang tepat makan mutu asuhan keperawatan juga dapat meningkat. 


\section{Daftar Pustaka}

Alamri, A, M., Rumayar,A, A., Kolibu, F, K. (2015). Hubungan Antara Mutu Pelayanan Perawat dan Tingkat Pendidikan dengan Kepuasan Pasien Peserta BPJS Kesehatan di Ruang Rawat Inap RSI Sitti Maryam Kota Manado. Jurnal Ilmiah Farmasi, 4(4), 241-251.

Amalia, Endra., Herawati, Lili., Nofriadi. (2018). Faktor-faktor Kelengkapan Pendokumentasian Asuhan Keperawatan di Instalasi Rawat Inap RSUD Lubuk Sikaping. Jurnal Seminr Kesehatan Perintis, 1(1), 2622-2256.

Atmanto, A, P., Aggorowati., Roffi, Muhammad. (2020). Efektifitas Pedoman Pendokumentasian Diagnosa dan Intervensi Keperawatan Berbasis Androis Terhadap Peningkatan Mutu Dokumentasi Keperawatan di Ruang Rawat Inap, Jurnal Keperawatan dan Kesehatan Masyarakat STIKES Cendekia Utama Kudus, 9(1), 83-92.

Budiono. (2016). Konsep Dasar Keperawatan. Jakarta : Pusdik SDM Kesehatan.

Butar-Butar, J., \& Simamora, R, H. (2016). Hubungan Mutu Pelayanan Keperawatan dengan Tingkat Kepuasan Pasien Rawat Inap di RSUD Pandan Kabupaten Tapanuli Tengah. Jurnal Ners Indonesia, 6(1), 51-64.

Dinarti., Mulyanti, Yuli. (2017). Dokumentasi Keperawatan. Jakarta : Pusdik SDM Kesehatan.

Hidayah, Nur. (2014). Manajemen Model Asuhan Keperawatan Profesional (MAKP) Tim dalam Peningkatan Kepuasan Pasien di Rumah Sakit. Jurnal Kesehatan, 7(2), 410-426.

Muhith, Abdul., Nursalam. (2012). Mutu Asuhan Keperawatan Berdasarkan Analisis Kinerja Perawat dan Kepuasan Perawat dan Pasien, Jurnal Ners, 7(1), 47-55.

Rachmania,Diana et.al. (2016). Pengembangan Instrumen Diagnosis \& Intervensi Keperawatan Bahasa Keperawatan Standar Berbasis (Nanda-I, Noc, Nic). Jurnal Keperawatan, 11(2), 157-163. 
Simamora, R. H., Bukit, E., Purba, J. M., \& Siahaan, J. (2017). Penguatan kinerja perawat dalam pemberian asuhan keperawatan melalui pelatihan ronde keperawatan di rumah sakit royal prima medan. Jurnal pengabdian kepada masyarakat, 23(2), 300-304.

Simamora, R. H. (2019). Socialization of Information Technology Utilization and Knowledge of Information System Effectiveness at Hospital Nurses in Medan, North Sumatra. Editorial Preface From the Desk of Managing Editor..., 10(9).

Supratti., Ashriady. (2016). Pendokumentasian Standar Asuhan Keperawatan di RSUD Mamuju Indonesia, Jurnal Kesehatan Manarang, 2(1), 44-51. 